\title{
Reglugerðarumhverfi frumkvöðla á Íslandi: Greining á stöðu og tækifærum til úrbóta
}

\author{
Gunnar Óskarsson og Hermann Pór Práinsson¹
}

\begin{abstract}
Ágrip
Par sem helstu atvinnugreinar Íslands eru bundnar stækkunartakmörkunum gegna aðrar atvinnugreinar auknu mikilvægi í íslenskum efnahag. Í pessu samhengi sinna frumkvöðlafyrirtæki pýðingarmiklu hlutverki, en til að pau geti dafnað og staðist samkeppni á erlendum mörkuðum parf sá reglugerðargrunnur sem fyrirtækin eru stofnuð á að vera nútímalegur, hagkvæmur og skilvirkur. Markmið pessarar greinar er að varpa ljósi á reglugerðarumhverfi frumkvöðla og greina hvort og pá hvar helstu tækifæri til úrbóta gætu legið. Rannsóknin byggir annars vegar á djúpviðtölum við sex frumkvöðla sem hafa stofnað og rekið nokkur pekkt frumkvöðlafyrirtæki og náð árangri á alpjóðlegum mörkuðum, eða fyrirtæki sem eru skemmra á veg komin og eru að fóta sig í umhverfi íslenskra frumkvöðlafyrirtækja. Hins vegar byggir rannsóknin á samanburði reglugerðarumhverfis á Íslandi við önnur lönd par sem slíkt umhverfi hefur verið skoðað í alpjóðlegum greiningum. Niðurstöðurnar sýna að reglugerðarumhverfi íslenskra frumkvöðla er að mörgu leyti hagkvæmara en í samanburðarlöndunum, en pó eru enn tækifæri til úrbóta.
\end{abstract}

\begin{abstract}
Since Iceland's main industries are subject to growth restrictions, other types of industry have acquired increased significance. For those new enterprises to prosper and gain competitive advantage on foreign markets, however, the firms in question must operate on a modern, economical and efficient regulatory basis. The aim of this article is to throw light on the regulatory environment of entrepreneurs and identify potential opportunities for improvement. On the one hand, the research is based on in-depth interviews with six entrepreneurs who have operated a number of well-known innovative enterprises which have succeeded on international markets, or companies which have further to go and are gaining a foothold in the Icelandic entrepreneurial environment. On the other hand, the research focuses on a comparison of the Icelandic regulatory environment to that of other countries where this environment has been subject to international analysis. The results indicate that the regulatory environment of Icelandic entrepreneurs is in many respects more beneficial than that of the comparison countries, although there is still room for improvement.
\end{abstract}

\section{JEL flokkun: M13; K20}

Lykilorð: Frumkvöðlastarfsemi; íslenskur efnahagur; reglugerðarumhvefi; lagaumhverfi

1 Gunnar Óskarsson, lektor, Háskóli Íslands. Netfang: gunnaros@hi.is. Hermann Pór Práinsson, MS í markaðsfræði og alpjóðaviðskiptum. Netfang: htt@nesskip.is.

This work is licensed under a Creative Commons Attribution 4.0 License. 
Keywords: Entrepreneurs; Icelandic economy; regulatory environment; legal environment

\section{The regulatory environment of entrepreneurs in Iceland: Analysis of current situation and opportunities for improvements}

\section{Inngangur}

Í fjölmörgum rannsóknum hefur verið sýnt fram á að frumkvöðlastarfsemi sé heillavæn hverju hagkerfi og leiði til aukins hagvaxtar (t.d. Acs, 2006; Black og Strahan, 2002; González-Sánchez, 2015). Frumkvöðlar sem beina athygli sinni að nýsköpun leika lykilhlutverk í pekkingarhagkerfinu, peir drífa hagvöxt og auka félagslega velferð (Baumol og Strom, 2007).

Í sögulegu samhengi hefur sjávarútvegur borið hitann og pungann af útflutningi Íslendinga, en með tíð og tíma hefur pessi staða breyst. Á síðustu áratugum hefur álútflutningur fest sig í sessi í íslensku efnahagslífi og á síðustu árum hefur ferðamannaiðnaður einnig tekið stór skref fram á við; í dag mynda pessar prjár atvinnugreinar stöplana sem íslenskt hagkerfi stendur á (Hagstofa Îslands, 2016). Erfitt getur pó reynst að stækka pessar greinar, par sem auðlindir eru takmarkaðar, svo sem magn af fiski og sú orka sem drífur áliðnaðinn. Par að auki pola íslenskar náttúruperlur ekki ótakmarkaðan ágang ferðamanna. Í skýrslu um Ísland sem stuðst er við í ýmsum stefnumarkandi ákvörðunum stjórnvalda, leggur ráðgjafarfyrirtækið McKinsey \& Company (2012) mikla áherslu á pessa stöðu og kannar hvaða leiðir Ísland geti farið til að auka hagvöxt hér á landi. Ein lykilniðurstaða skýrslunnar er að nýsköpun og frumkvöðlastarfsemi purfi að gegna veigamiklu hlutverki til hagvaxtar og sköpunar atvinnutækifæra.

Íslendingar standa framarlega í nýsköpun meðal hátekjulanda, en í könnun sem byggð er á margvíðum mælikvarða um nýsköpun og framkvæmd var árið 2015 var Ísland meðal efstu sæta hátekjupjóða (Wunsch-Vincent, Lanvin og Dutta, 2015). Rannsókn sem framkvæmd var árið 2010 bendir jafnframt til að Íslendingar hafi mun meiri áhuga á að stofna eigin fyrirtæki og hefja eigin rekstur en meðaltal peirra landa sem eru í Evrópusambandinu. Rannsóknin gaf jafnframt til kynna að áhugi Íslendinga á að gerast frumkvöðlar væri mikill, en hún sýndi að 51,2\% íslensku pjóðarinnar töldu heillandi hugsun að reka sitt eigið fyrirtæki, 10,6\% Íslendinga hugðu markvisst að pví að stofna fyrirtæki, 7,4\% lögðu fjármagn til hliðar og 3,3\% pjóðarinnar höfðu látið slag standa og eignast eða störfuðu í fyrirłæki sem var yngra en priggja og hálfs árs gamalt (Kelley, Bosma og Amorós, 2011b). Er petta hátt hlutfall í samhengi við helstu samanburðarpjóðir Íslendinga (Global Entrepreneurship Monitor, 2011; McKinsey, 2012). Samkvæmt skýrslu OECD (2016) um efnahagshorfur hafa Íslendingar lagt aukna áherslu á nýsköpun frá efnahagshruninu 2008. Prátt fyrir ofangreindar forsendur gefa nýlegar mælingar til kynna að Íslendingar standi helstu samanburðarpjóðum að baki hvað nýsköpun varðar, en peir skipuðu 25. sæti í Bloomberg Innovation Index á meðan aðrar Norðarlandapjóðir voru í 2. - 14. sæti (Jamrisko og Lu, 2017).

Árangur frumkvöðlafyrirtækja ræðst af mörgum samverkandi páttum, sem snúa bæði að einstaklingunum (t.d. viðhorf, getu og löngun) og stofnanaumgjörðinni eða starfsumhverfinu almennt (Ács, Autio og Szerb, 2014). Sérhver páttur getur myndað flöskuháls og pannig takmarkað möguleika á árangri. Einn af peim páttum sem hafa áhrif á árangur frumkvöðlafyrirtækja er reglugerðarumhverfið, en pær pjóðir sem setja frumkvöðlafyrirtækjum hentugt umhverfi örva nýsköpun og frampróun fyrirtækjanna. Velgengni frumkvöðla í ákveðnu hagkerfi leiðir par að auki af sér velgengni annarra aðila og dregur að einstaklinga og fjármagn til frekari frumkvöðlastarfsemi (Litan, 2014). •að er pví mikilvægt fyrir stjórnvöld að skapa umhverfi sem gerir frumkvöðlum kleift að nýta pann drifkraft sem í peim býr. Vel útfært reglugerðarumhverfi gefur frumkvöðlum traustan grunn til að hefja rekstur sinn á og getur jafnvel hraðað uppbyggingu frumkvöðlafyrirtækja, sér- 
staklega í erfiðu árferði (Mayer-Schonberger, 2003, 2010). Samkvæmt greiningu OECD á horfum í vísindum, tækni og atvinnugreinum (e. OECD science, technology and industry outlook) er reglugerðarumhverfið á Îslandi ekkert sérstaklega hliðhollt frumkvöðlum, m.a. vegna ípyngjandi krafna um skrifræði (OECD, 2012, bls. 308). •að er pví mikilvægt að fá nánari innsýn í hvort tækifæri til að bæta árangur frumkvöðla á Íslandi liggi að einhverju leyti í reglugerðarumhverfi peirra. Pessi rannsókn byggir á greiningu höfunda á reglugerðarumhverfi frumkvöðla sem unnin var fyrir meistararitgerð í lok árs 2014 ásamt samantekt á helstu breytingum sem átt hafa sér stað frá pví að greiningin fór fram. Rannsóknarspurningin sem leitast er við að svara er eftirfarandi:

Hvernig er staðan í reglugerðarumhverfi frumkvöðla á Íslandi og hvar gætu helstu tækifæri stjórnvalda til úrbóta legið með hliðsjón af stöðunni í löndum sem við getum helst borið okkur saman við?

Rannsóknarspurningin leitar ekki einungis svara við pví hver staðan á Íslandi er, heldur einnig hver hún er í samanburði við pað sem gerist erlendis, en hafa verður í huga að í vaxandi mæli eru fyrirtæki í alpjóðlegri samkeppni og pví mikilvægt að starfsskilyrði íslenskra fyrirtækja séu sambærileg pví sem gerist hjá mögulegum samkeppnisaðilum. Pá innifelur rannsóknarspurningin takmarkanir í samanburði við reglugerðarumhverfi í öðrum löndum, en af ýmsum ástæðum, svo sem vegna mannfjölda, menningar, efnahagslegrar umgjarðar o.fl. er mikilvægt að takmarka samanburðinn við lönd sem raunhæft er að við berum okkur saman við (Fernández-Serrano og Romero, 2014). Leitað verður svara við rannsóknarspurningunni með tvennum hætti, annars vegar með eigindlegri rannsókn sem byggir á viðtölum við frumkvöðla, sem sumir hverjir hafa víðtæka reynslu af rekstri frumkvöðlafyrirtækja bæði á Íslandi og erlendis, og hins vegar á samanburði á reglugerðarumhverfi á Íslandi við aðstæður erlendis byggt á fyrirliggjandi gögnum. Samspil pessara aðferða varpar bæði ljósi á aðstæður frumkvöðla á Íslandi og gerir jafnframt mögulegt að greina pau tækifæri til úrbóta sem raunhæft ætti að vera að innleiða hér á landi. Í fyrri hluta greinarinnar verður gerð grein fyrir fræðilegum viðmiðum, en pví næst fjallað um framkvæmd pessarar rannsóknar og niðurstöður hennar. Loks er rýnt í pær breytingar sem hafa verið innleiddar frá pví rannsóknin var framkvæmd og á grundvelli peirra upplýsinga dregin fram möguleg tækifæri sem enn eru til staðar fyrir íslensk stjórnvöld til að bæta reglugerðarumhverfið.

\subsection{Fræðileg umræða}

Rannsóknir sýna að prír meginpættir hafa áhrif á árangur frumkvöðlafyrirtækja og framlag peirra til samfélagsins og efnahagslífsins; tækifæri, hæft starfsfólk og auðlindir (Ahmad og Hoffmann, 2008). Ytra umhverfi hefur aftur á móti áhrif á hversu miklum árangri fyrirtækin geta náð. Í nokkrum rannsóknum hefur sjónum verið beint að ytra umhverfi frumkvöðlafyrirtækja. Global Entrepreneurship Monitor (GEM) er ein pekktasta rannsókn á pví sviði, en hún byggir á greiningu á starfsemi og umgjörð frumkvöðlafyrirtækja í fjölda ríkja (Acs, Arenius, Hay og Minniti, 2004). Acs o.fl. (2014) töldu fyrri rannsóknir búa yfir of miklum takmörkunum og að samanburður á árangri pyrfti að vera grundvallaður á heildarskipulagi pjóða á frumkvöðlastarfsemi (e. national systems of entrepreneurship), sem er drifið áfram af einstaklingum, en stofnanaumhverfið stjórni hins vegar mögulegum aðgerðum og hefur pannig áhrif á afrakstur eða árangur einstaklinganna. Peir leggja jafnframt áherslu á að jafnvel smávægileg frávik frá heppilegustu skilyrðum geti myndað flöskuháls sem takmarkar mögulegan árangur frumkvöðla og jafnframt að ef mikill munur er á einstaka páttum, pá séu áhrifin enn meiri. Рað er pví mikilvægt að allir pættir í umhverfi frumkvöðlafyrirtækja séu pess eðlis að peir stuðli að sem mestum árangri og jafnframt, svo fyrirtækin séu samkeppnishæf á alpjóðamarkaði, er mikilvægt að skilyrði fyrirtækjanna séu ekki lakari en pau eru hjá fyrirtækjum í öðrum löndum. 
Reglugerðarumhverfi er hluti af ytra umhverfi fyrirtækja og hefur áhrif á hversu miklum árangri frumkvöðlafyrirtæki geta náð, en helstu áhrif sem reglugerðarumhverfið hefur er hversu auðvelt er að stunda viðskipti, inngönguhindranir og hvata til að stofna fyrirtæki. Reglugerðarumhverfið tekur til krafna um skrifræði, gjöld við stofnun fyrirtækja, skrifræði á vaxtarskeiði fyrirtækja, reglur um gjaldprot, reglur um öryggismál, heilsuog umhverfi, laga um vörur og framleiðslu, laga um starfsmannamál, samkeppnislaga, höfundaréttarlaga og dómsmála- og lagaumgjarðar (Ahmad og Hoffmann, 2008; Lunati, 2010; Napier o.fl., 2012).

Reglugerðarumhverfi ætti ekki að vera fyrirtækjum fjötur um fót heldur að greiða götu peirra og jafnvel stuðla að bættri frammistöðu (Braunerhjelm, Desai og Eklund, 2015; Fuentelsaz, Gonzalez, Maicas og Montero, 2015). Pannig getur vel útfært reglugerðarumhverfi stuðlað að auknum markaðstækifærum, eða haft áhrif á viðskiptalega starfshætti sem bæta skilvirkni eða samkeppnishæfni (Kitching, Hart og Wilson, 2013). Vel heppnað reglugerðarumhverfi getur stuðlað að jöfnum tækifærum og auðveldað fyrirtækjum starfsemi sína (Mayer-Schonberger, 2010). Mörg dæmi eru til um lög sem stuðla að jafnari viðskiptaumhverfi, svo sem aukið frelsi í farsímaviðskiptum sem opnað hefur möguleika fyrir frumkvöðla til að bjóða neytendum nýja valkosti, frelsi í netviðskiptum, afnám sérréttinda í flugsamgöngum og pannig mætti lengi telja. Einkaréttar- og höfundarréttarlög eru dæmi um aðgerðir sem vernda möguleika frumkvöðla til að njóta ávinnings af uppfinningum sínum (Graham, Merges, Samuelson og Sichelman, 2009), en par er góð og traust lagaumgjörð forsenda árangurs. Pá er mikilvægt að lögin skapi fyrirtækjum forsendur og vernd til að pau geti fullnægt skyldum sínum og myndi umgjörð sem tryggir að samningsaðilar peirra eigi ekki annarra kosta völ en að standa við gerða samninga. Petta er ekki síst mikilvægt pegar lítil fyrirtæki fara inn á markað par sem stór og öflug fyrirtæki eru pegar til staðar. Til að gera pessa stöðu mögulega parf regluverkið að ná tveimur markmiðum; annars vegar að skapa nýjum fyrirtækjum svigrúm til að koma inn á markaðinn, og hins vegar að koma á löggjöf sem tryggir sjálfbæra samkeppni á markaði (Mayer-Schonberger, 2010).

Til að fjalla á greinargóðan hátt um petta viðfangsefni og ná fram aðalatriðunum pess er reglugerðarumhverfi frumkvöðla í pessari grein skipt í prjá meginflokka; skráningu og skrifræði, almenna lagaumgjörð, og skattaumhverfi, en pessir pættir hafa bæði áhrif á hvata frumkvöðla til að stofna fyrirtæki og rekstrarskilyrði pegar pau eru tekin til starfa (Ahmad og Hoffmann, 2008; Djankov, 2009).

\subsection{Skráning og skrifræði}

Stjórnvöld semja reglugerðir um skráningu og gera kröfur til skráningar til að tryggja að fyrirtækin uppfylli lágmarksskilyrði til að útvega vörur og pjónustu á markað (Darnihamedani, Block, Hessels og Simonyan, 2015; Djankov, La Porta, Florencio og Shleifer, 2002). Pessir ferlar fela í sér kostnað og útheimta tíma sem oft og tíðum er takmarkaður, en í sumum tilfellum er mikilvægt að koma vörunni sem fyrst á markað af samkeppnisástæðum, en pá er tíminn enn dýrmætari en ella. Pví fleiri sem skrefin eru og peim mun meiri upplýsinga sem krafist er, pví lengri tíma tekur að uppfylla kröfurnar, en pað hefur áhrif á vilja frumkvöðla til að stofna fyrirtæki (Levie og Autio, 2011). Sama gildir um skrásetningargjöld og annan kostnað við að stofna fyrirtækis, pví meiri sem hann er, peim mun minni áhuga hafa frumkvöðlar á að stofna fyrirtæki (Djankov, 2009). Af pessum ástæðum ættu kröfur um skriffinsku og skráningargjöld að vega eins lítið og mögulegt er, en megináherslan ætti að vera að opna aðgengilega leið fyrir frumkvöðla til að hrinda hugmyndum sínum í framkvæmd og njóta ávinnings peirra.

Kröfur um skriffinsku taka ekki einungis til pess pegar verið er að stofna fyrirtæki, heldur halda pær áfram eftir að rekstur er hafinn, svo sem kröfur um framleiðslu pegar við á, kröfur um starfsmannamál og ýmsar skyldur sem peim fylgja, endurskoðun og skattframtöl. Til eru dæmi um að stjórnvöld hafi sparað frumkvöðlafyrirtækjum mikið 
fjármagn með pví að minnka slíkar kröfur svo sem á Nýja Sjálandi par sem frumkvöðlastarfsemin er mjög öflug (Djankov o.fl., 2002). Umfangsmikið reglufargan og skortur á gegnsæi um pær reglur sem frumkvöðlar purfa að uppfylla til að stofna fyrirtæki getur haft neikvæð áhrif, bæði á fyrirtækið sem parf að kljást við dýrar og tímafrekar verklagsreglur, sem og samfélagið sjálft (Keuschnigg og Nielsen, 2004; Klapper, Laeven og Rajan, 2006). Раð eru pví ekki einungis reglurnar sjálfar sem hafa áhrif, heldur einnig hversu aðgengilegar upplýsingar um pær eru og hversu góð aðstoð og leiðsögn stendur frumkvöðlum til boða við að uppfylla pær kröfur sem til peirra eru gerðar.

Lög, staðlar og reglugerðir eru nauðsynleg til að auðvelda próun viðskiptasamfélags, en pegar fyrirtæki eiga viðskipti sín á milli purfa pau að geta verið viss um að hægt sé að framfylgja gerðum samningum og að viðsemjendur geti ekki á auðveldan hátt komist undan peim og jafnvel stolið hugmyndum frá frumkvöðlunum. Prátt fyrir petta, getur verið frumkvöðlafyrirtækjum óhagstætt að starfa í umhverfi par sem flókið og krefjandi laga- og reglugerðarumhverfi er til staðar (Fernández-Serrano og Romero, 2014; Klapper o.fl., 2006). Mörg frumkvöðlaríkustu lönd heimsins eru pau sem setja minnstar lagalegar skyldur á herðar nýstofnaðra fyrirtækja, líkt og Singapúr, Nýja- Sjáland og Kanada (Röhl, 2016). Pau ríki sem setja ípyngjandi lög og háan stofnkostnað fyrirtækja leiða í flestum tilfellum til minni áhuga einstaklinga á að gerast frumkvöðlar en á sér stað í öðrum ríkjum (Darnihamedani o.fl., 2015; Klapper o.fl., 2006).

\subsection{Almenn lagaumgjörð}

Meðal peirra laga sem eru frumkvöðlafyrirtækjum sérstaklega mikilvæg eru samkeppnislög og lög um einkarétt og höfundarétt, en pau skapa peim aðstæður til að keppa á markaði án markaðsmisnotkunar frá öflugum fyrirtækjum sem pegar eru til staðar (Chowdhury, Terjesen og Audretsch, 2015). Petta er sérstaklega mikilvægt par sem starfsemi frumkvöðla byggir í flestum tilfellum á nýstárlegum hugmyndum, en einkum pá er mikilvægt að til staðar sé löggjöf sem geri peim kleift að njóta afraksturs hugmyndarinnar áður en aðrir aðilar á markaðnum geti hermt eftir og stolið hugmyndinni (Dutta, Lanvin og WunschVincent, 2016). Til að frumkvöðlafyrirtæki geti unnið hugmyndum sínum brautargengi er mikilvægt að upplýsingar um löggjöfina séu aðgengilegar, auðskiljanlegar og fyrirsjáanlegar (Evans og Gabel, 2014).

Lög um gjaldprot eru mikilvæg til að frumkvöðlar geti farið af stað með hugmynd án pess að eiga á hættu að fyrirgera möguleikum sínum til annarra starfa eða að byrja aftur ef ekki tekst vel til (Armour og Cumming, 2008). Sú áhætta fylgir reyndar, að fjárfestar og lánveitendur purfa að bera kostnaðinn, en, í fyrsta lagi kann að vera að peir hafi hvort sem er verið búnir að tapa fjármununum auk pess sem pað getur verið í págu samfélagsins að ýta undir áhuga á pátttöku í frumkvöðlastarfsemi með pessum hætti (Armour og Cumming, 2008; Mayer-Schonberger, 2010). Рað skiptir einnig máli að ekki sé of flókið og seinlegt að fara í gegnum gjaldprotameðferð. Pví færri sem skrefin eru og pví fljótar sem gjaldprotameðferðin gengur fyrir sig, peim mun líklegra er að frumkvöðlar telji áhugavert að fara af stað með nýja hugmynd, jafnvel pó pví fylgi nokkur áhætta (Napier o.fl., 2012).

\subsection{Skattaumhverfi}

Rannsóknir sýna að pað eru ekki einungis álagðir skattar sem hafa áhrif á áhuga á pví að gerast frumkvöðlar og vilja peirra til að halda áfram rekstri, heldur einnig flækjustigið í skattkerfinu. Pannig leiddi rannsókn Braunerhjelm og Eklund (2014) í ljós, að við 10 prósenta aukningu á sköttum minnkar áhuginn á pví að stofna frumkvöðlafyrirtæki um 3\% og að sambærileg aukning á flækjustigi í skattkerfinu hefur sömu áhrif. Í Evrópusambandinu hefur verið lögð áhersla á að bjóða smáum fyrirtækjum upp á einfaldari leið við skattframtöl með góðum árangri, en pað sparar peim kostnað og skapar peim auk pess tækifæri til að vernda mikilvægar upplýsingar sem annars yrðu opnar samkeppnisaðilum (Kitching, Kašperová, Blackburn og Collis, 2011). Í rannsóknarramma OECD og Nordic 
Growth Ownership (Nger) eru prír meginflokkar af sköttum sem hafa áhrif á áhuga á stofnun og pátttöku í frumkvöðlastarfsemi, tekjuskattar sem lagðir eru á frumkvöðlana sjálfa, tekju- og eignaskattar sem lagðir eru á fyrirtæki og fjárfestingaskattar, eða skattar sem lagðir eru á eign fjárfesta í fyrirtækjunum (Ahmad og Hoffmann, 2008; Napier o.fl., 2012).

\section{Rannsóknaraðferð}

Til að ná báðum markmiðum rannsóknarinnar, annars vegar að varpa ljósi á reglugerðarumhverfi frumkvöðla á Íslandi og hins vegar að greina tækifæri til úrbóta er ekki nægjanlegt að skoða íslenskt umhverfi eitt og sér, heldur parf að bera pað saman við aðstæður í löndum sem raunhæft er að bera Ísland saman við. Í pessu skyni er stuðst við blandaða rannsóknaraðferð, en hún hentar vel fyrir rannsóknarspurninguna sem leitar svara við stöðu reglugerðarumhverfis á Íslandi og hvaða tækifæri til úrbóta eru í samanburði við helstu nágrannapjóðir okkar. Ástæðan er sú, að starfsumhverfi íslenskra fyrirtækja parf að vera sambærilegt við pað sem gerist í öðrum pjóðum ef fyrirtækin eiga að geta staðist samkeppni við aðila á alpjóðamörkuðum. Samanburður á innsýn íslenskra frumkvöðla við stöðuna í helstu nágrannalöndum okkar skapar tækifæri til að greina hvar tækifæri til úrbóta gætu legið. Wooley (2009) bendir á að líta megi á megindlega og eigindlega rannsóknaraðferð sem sampættar að svo miklu leyti sem notkun aðferðanna er greinilega tengd í sömu rannsókninni með peim hætti að sampættingin varpi skýrara ljósi á niðurstöðuna og að ávinningurinn sé meiri en samanlögð niðurstaða hvorrar aðferðarinnar fyrir sig (bls. 7). Í pessu skyni byggir rannsóknin annars vegar á alpjóðlegri greiningu á grundvelli fyrirliggjandi gagna úr megindlegri rannsókn par sem kannað var reglugerðarumhverfi Norðurlandanna og hins vegar á eigindlegri rannsókn sem gefur kost á að öðlast dýpri skilning á efninu og fá innsýn í skoðanir viðmælenda (Kristiánsdóttir og DeTurk, 2013). Ólíkum leiðum er beitt við blandaða rannsóknaraðferð, ýmist er hvor aðferðin kynnt fyrir sig og síðan dregnar saman niðurstöður úr báðum peirra eða að fjallað er um niðurstöðurnar sameiginlega (Tashakkori og Creswell, 2007). İ pessari rannsókn var fyrri aðferðinni beitt par sem hún var talin varpa skýrari mynd af niðurstöðunni (Bryman, 2007). Pessi aðferð opnar jafnframt leiðir til að fá nánari innsýn í pætti sem nýttir hafa verið í fyrri rannsóknum og draga fram mikilvægar áherslur, að minnsta kosti við ákveðnar sér aðstæður, svo sem á Íslandi, en geta engu að síður átt við í öðru umhverfi (Ahmad og Hoffmann, 2008). Hér á eftir verður fjallað um báðar rannsóknaraðferðirnar og niðurstöður dregnar síðan úr báðum aðferðunum sameiginlega.

\subsection{Alpjóðlegar greiningar}

Í tvígang hafa samtökin Nordic Innovation unnið rannsókn á reglugerðarumhverfi frumkvöðla á Norðurlöndunum undir heitinu Nordic Growth Entrepreneursip Review (Nger), fyrst árið 2007 og síðan 2012. Markmið rannsóknarinnar er að koma auga á leiðir sem gætu stuðlað að pví að efla viðskipti og frumkvöðlastarfsemi í einstaka löndum (Napier o.fl., 2012). Enn sem komið er hefur rannsókn á reglugerðarumhverfinu ekki verið endurtekin. Í niðurstöðum síðustu skýrslunnar voru styrkleikar Íslands taldir liggja í regluverki, frumkvöðlamenningu og frumkvöðlafærni (Napier o.fl., 2012). Pessar niðurstöður voru í samræmi við sambærilega rannsókn frá OECD, en par skipaði Ísland sjöunda sæti af 36 OECD ríkjum er varðar samkeppnishæfni í reglugerðarumhverfi frumkvöðla (Ahmad og Hoffmann, 2008). Eins og fram kemur í töflu 1, eru pættirnir sem teknir eru til skoðunar að flestu leyti svipaðir í báðum greiningunum. 
Tafla 1. Pættir í reglugerðarumhverfi frumkvöðla

\begin{tabular}{lcc}
\hline Pættir & Nger & OECD \\
\hline Kröfur um skriffinsku & $X$ & $X$ \\
Kröfur um skriffinsku fyrir inngöngu & $\mathrm{X}$ \\
Kröfur um skriffinsku í vexti & $\mathrm{X}$ \\
Gjaldprotalöggjöf & $\mathrm{X}$ & $\mathrm{X}$ \\
Vöru- og starfsmannalöggjöf & & $\mathrm{X}$ \\
Löggjöf um vörur & & $\mathrm{X}$ \\
Löggööf um atvinnumarkað & & $\mathrm{X}$ \\
Öryggis-, heilsu- og umhverfislöggjöf & $\mathrm{X}$ \\
Dóms- og lagaumgjörð & & $\mathrm{X}$ \\
Samfélags- og öryggismál & $\mathrm{X}$ & $\mathrm{X}$ \\
Tekjuskattar & & $\mathrm{X}$ \\
Tekju- og eignaskattar & $\mathrm{X}$ & \\
Fyrirtækja- og fjárfestingaskattar & & \\
Einkaréttarlöggjöf og staðlar & & \\
\hline
\end{tabular}

Greiningin frá OECD hentar að mati höfunda ekki eins vel í pessa rannsókn og greiningin frá Nordic Innovation, annars vegar par sem OECD greiningin er unnin 2007, eða fyrir efnahagshrunið á Íslandi árið 2008, pegar aðstæður voru töluvert ólíkar og hins vegar par sem hún er ekki eins ítarleg, en í Nger er hægt að skoða nánar pær breytur sem standa að baki hverri einkunn fyrir sig og gefur hún pví betri mynd af stöðu Íslands. Pá er Nger greiningin sérstaklega áhugaverð par sem hún leggur áherslu á stöðu Norðurlanda, sem Islendingar bera sig gjarnan saman við, fremur en önnur lönd.

\subsection{Eigindleg rannsókn}

Í eigindlegri aðferðafræði er lögð höfuðáhersla á að pátttakandi setji fram sína túlkun á veruleikanum og pví sé mikilvægt að rannsakandi afli sér upplýsinga um pá merkingu sem pátttakandi leggur í pá túlkun (Merriam og Tisdell, 2015). Í pessari rannsókn voru tekin djúpviðtöl; par notar rannsakandinn viðtalsramma, en viðmælendur tjá sig frjálslega um viðfangsefnið sem rannsóknin snýr að og hafa par tækifæri til að lýsa upplifun sinni af pví með sínum eigin orðum (Orbe, 1998). Rannsakendur beittu pessari aðferð og notuðu hálfstaðlaðan viðtalsramma með opnum spurningum, en sú nálgun gefur viðmælendum tækifæri til að tjá sig um málefnið á sinn eigin hátt með eins lítilli aðkomu rannsakanda og unnt er (Merriam og Tisdell, 2015).

Viðmælendur voru valdir með pað að markmiði að geta gefið innsýn í hugarheim frumkvöðla á Íslandi. Allir hafa viðmælendur komið að stofnun eða rekstri frumkvöðlafyrirtækis og flestir starfa enn á peim vettvangi. Sumir viðmælenda voru enn á frumstigum síns fyrirtækis, en aðrir voru í pann veginn að koma vörunni sem fyrirtækið var að próa á markað. Pá var einnig rætt við einstaklinga sem hafa pegar lokið pessum stigum og selt fyrirtæki sín. Höfundar reyndu jafnframt að fá viðmælendur sem höfðu komið að mismunandi tegundum fyrirtækja til að fá innsýn í hugarheim frumkvöðla úr sem breiðustu litrófi efnahagslífsins. Leitað var til sex einstaklinga sem sumir hverjir höfðu komið að nokkrum fyrirtækjum, en pað var talið fullnægjandi til að öðlast góða innsýn í hugarheim frumkvöðla vegna peirrar víðtæku reynslu sem viðkomandi aðilar búa yfir. Nöfn fyrirtækja og viðmælenda verða ekki gefin upp í rannsókninni, heldur verður vísað til bókstafa, A, B, C, D, E og F sem standa fyrir fyrirtækin sem viðmælendur störfuðu fyrir pegar viðtölin fóru fram (sjá nánar töflu 2). Rétt er að taka fram að par sem einn viðmælandinn hafði unnið fyrir mörg frumkvöðlafyrirtæki (raðfrumkvöðull), endurspegluðu viðtölin reynslu úr fleiri fyrirtækjum en peim sex sem viðmælendur störfuðu hjá pegar viðtölin 
fóru fram. Pau voru tekin upp með leyfi viðmælenda, afrituð og greind samkvæmt viðurkenndum aðferðum. Við framkvæmd rannsóknarinnar kom fram mettun pegar síðustu viðtölin fóru fram, en hún á sér stað pegar upplýsingar sem fram koma fara að endurtaka sig og sömu pemu koma fram í gagnagreiningu, en pau voru skráning og skrifræði, almenn lagaumgjörð og skattaumhverfi.

Tafla 2. Viðmælendur, verkefni og staða próunar

\begin{tabular}{|c|c|c|}
\hline Viðmælandi & Reynsla & Staða próunar \\
\hline A & Hugbúnaður, hönnun á greiðsluappi & Hönnun á lokastigi \\
\hline B & Grafískur hönnuður, app fyrir samfélagsmiðla og tengslanet & Vara í próun \\
\hline C & Viðskiptafræðingur og fjármálastjóri. Hugbúnaður fyrir bankaviðskipti & Vara komin á markað \\
\hline $\mathrm{D}$ & $\begin{array}{l}\text { Stofnandi og framkvæmdastjóri. Framleiðsla á sérhæfðum } \\
\text { barnaleikföngum }\end{array}$ & Komin langt á veg í próun \\
\hline E & $\begin{array}{l}\text { Stofnun og próun nokkurra frumkvöðlafyrirtækja. Próun gagnabanka } \\
\text { fyrir viðskiptagreind }\end{array}$ & Vara komin á markað \\
\hline $\mathrm{F}$ & $\begin{array}{l}\text { Raðfrumkvöðull, vinnur að hugbúnaði fyrir gagna- og atburðagreiningu } \\
\text { í rauntíma }\end{array}$ & Vara komin langt í próun \\
\hline
\end{tabular}

Viðtölin fóru fram í árslok 2014 og tóku um 40 - 50 mínútur hvert peirra.

\section{Niðurstöður}

\subsection{Erlendar greiningar}

Til að bera reglugerðarumhverfi á Íslandi saman við önnur lönd var leitað fanga í fyrirliggjandi rannsóknir. Tvær rannsóknir komu helst til greina, annars vegar rannsókn sem unnin var fyrir ríki innan OECD (Lunati, 2010) og hins vegar svokölluð Nger greining, en í henni var tekið fyrir reglugarðarumhverfið á Norðurlöndunum (Napier o.fl., 2012). Að undangenginni skoðun á pessum greiningum reyndist gagnlegast fyrir pessa rannsókn að taka mið af stöðunni á hinum Norðurlöndunum og styðjast við Nger greininguna, en algengt er að miðað sé við Norðurlöndin af menningarlegum ástæðum, svo og par sem mannfjöldi peirra er nær pví sem er á Íslandi en í mörgum öðrum vestrænum löndum. Niðurstöður greiningarinnar er að finna í töflu 3. Skalinn í töflunni er byggður upp pannig að sú pjóð sem er með hagstæðustu skilyrði fær einkunnina 100 að hámarki fyrir einstaka undirpætti og sú pjóð sem er með slökustu skilyrðin fær að lágmarki einkunnina 0. Pví næst var reiknuð út meðaltal allra undirpáttanna fyrir hvern pátt. Kvarðinn var síðan notaður til að meta stöðuna í einstaka páttum í sérhverju landi út frá hlutfallslegum samanburði á grundvelli niðurstaðnanna í öllum löndunum. Í niðurstöðunum var jafnframt tekið mið af stöðunni í öðrum löndum OECD. Síðan eru allir pættirnir vegnir saman og reiknaður út heildarmælikvarði út frá pví hversu góð skilyrðin eru í viðkomandi pætti. Eins og fram kemur í töflunni, pá er staðan á Íslandi nokkuð góð varðandi fyrstu fjóra pættina; kröfur um skriffinsku byrðar, gjald protameðferð, vöru- og vinnulöggjöf og meðferð og fullnustu dómsmála, pó svo að par séu reyndar enn tækifæri til úrbóta. Hins vegar er staðan varðandi samkeppnislöggjöf, tekjuskatta einstaklinga, fyrirtækja- og eignskatta og einkaréttarlöggjöf og staðla ekki góð. Pað vekur pó athygli að einkunn fyrir tekjuskatta einstaklinga er slök á öllum Norðurlöndunum. Petta á ennfremur við um fyrirtækja- og eignaskatta, en prátt fyrir að Ísland skori ekki hátt í pessum páttum, pá er staðan ekki lakari en á hinum Norðurlöndunum. 
Tafla 3. Reglugerðarumhverfi á Norðurlöndum

\begin{tabular}{lccccc}
\hline & Danmörk & Finnland & Ísland & Noregur & Svípjód \\
\hline Kröfur um skriffinsku & 82 & 80 & 79 & 77 & 87 \\
Gjaldprotameðferð & 88 & 90 & 87 & 95 & 75 \\
Vöru- og vinnulöggjöf & 100 & 46 & 79 & 12 & 5 \\
Almenn lagaumgjörð & 50 & 68 & 84 & 75 & 83 \\
Samkeppnislöggjöf & 58 & 72 & 43 & 61 & 23 \\
Tekjuskattar einstaklinga & 10 & 28 & 42 & 29 & 13 \\
Fyrirtækja- og eignaskattar & 47 & 48 & 67 & 30 & 50 \\
Einkaréttarlöggjöf og staðlar & 87 & 100 & 55 & 81 & 84 \\
\hline
\end{tabular}

Samantekt höfunda, byggð á Nger (Napier o.fl., 2012)

Einn af útgangspunktum greiningar Nger yfirlitsins á Íslandi eru pær takmarkanir sem stærð íslenska hagkerfisins og hinn smái markaður sem hér er við lýði setja vaxtarmöguleikum fyrirtækja. Pessar takmarkanir eru meðal ástæðna fyrir pví að mjög fá íslensk fyrirtæki verða stór innan tíu til fimmtán ára frá stofnun. Pví er nauðsynlegt, samkvæmt greiningunni, að fyrirtæki sem starfrækt eru á Íslandi hafi tækifæri til að stefna á erlendan markað (Napier o.fl., 2012).

Í Nger greiningunni er jafnframt að finna samanburð á próun reglugerðarumhverfis yfir tímabilið 2008-2012. Yfirlit yfir próun reglugerðarumhverfis á Íslandi er að finna í töflu 4, en í henni kemur í ljós að reglugerðarumhverfið á Íslandi versnaði í samanburði við hin Norðurlöndin á tímabilinu, mest hvað varðar fyrirtækja- og eignaskatta annars vegar og hins vegar varðandi einkaréttarlöggjöf og staðla (Napier o.fl., 2012).

Tafla 4. Próun reglugerðarumhverfis á Íslandi 2008-2012

\begin{tabular}{lcccc}
\hline & 2008 & 2010 & 2012 & Breyting 2008-12 \\
\hline Kröfur um skriffinsku & 83 & 80 & 79 & -4 \\
Gjaldprotameðferð & 85 & 84 & 87 & +2 \\
Vöru- og vinnulöggjöf & 81 & 81 & 79 & -2 \\
Almenn lagaumgjörð & 87 & 86 & 84 & -3 \\
Samkeppnislöggjöf & 49 & 45 & 43 & -6 \\
Tekjuskattar einstaklinga & 46 & 47 & 42 & -4 \\
Fyrirtækja- og eignaskattar & 89 & 73 & 67 & -22 \\
Einkaréttarlöggjöf og staðlar & 72 & 67 & 55 & -17 \\
\hline
\end{tabular}

Samantekt höfunda, byggð á Nger (2012)

Í umfjöllun í skýrslunni um próunina á Íslandi er tekið fram að staðan sé nokkuð góð, en pó lögð rík áhersla á að Ísland er eina ríkið á Norðurlöndunum sem ekki hefur bætt umhverfi frumkvöðlafyrirtækja á samanburðartímabilinu. Er pessi staða ekki síst tengd efnahagshruninu og peim aðgerðum sem stjórnvöld gripu til í kjölfar pess.

\subsection{Eigindleg rannsókn}

Áður en viðtölin fóru fram var próaður spurningalisti á grundvelli undirkafla Nger yfirlitsins. Viðmælendur voru spurðir um; hvort peir teldu reglugerðarumhverfið á Íslandi hentugt frumkvöðlafyrirtækjum, hvað peim fyndist um kostnað við að hefja rekstur, hvort peir teldu reglugerðarumhverfið skapa nægjanlega hvata fyrir frumkvöðlastarfsemi, hvort peim fyndist skattaumgjörðin henta frumkvöðlafyrirtækjum, hvort peir hefðu hugmyndir eða reynslu af reglugerðarumhverfi erlendis sem gagnlegt væri að innleiða á Íslandi að 
peirra mati og hvort peir vildu koma einhverju á framfæri í lokin. Eftir að viðtölin voru afrituð voru pau greind með aðferðum eigindlegrar aðferðar og niðurstöðurnar flokkuð í pemu.

\subsubsection{Skráning og skrifræði}

Viðmælendur töldu að flækjustigið í löggjöfinni væri hamlandi, en til að vega upp á móti pví hafa íslenskir frumkvöðlar í sumum tilfellum fengið styrk fyrir stuðning við að komast í gegnum flækjustigið og hefur pað gert gæfumuninn.

Detta er svolitið flækjustig og maður er að gera samninga við svo mismunandi. Detta eru alveg allt aðrir hlutir að vinna að og ég var alveg ný i pessu og ég varð að stofna fyrirtæki og fá sampykktir. Hvað er pað? Dað er einhvern vegin ekkert $i$ pessu lagalega umhverfi sem er sjálfgefið og maður skilur petta ekki pegar maður er að horfa á pað í fyrsta sinn.

$\cdots$

En svo stofna ég í rauninni bara fyrirtækið mjög fljótt og pá fer pað bara svona inn í eitthvad ferli. Ég fékk reyndar KPMG, semsagt vinnutíma frá peim svo peir hjálpuðu mér að búa um stofnun fyrirtækisins og búa til allar sampykktirnar og ég bara purfti að mæta og skrifa undir. Pað var mjög pægilegt (viðmælandi D).

Viðmælandi A fjallaði um flækjustigið, bæði í styrkjakerfinu og að stofna fyrirtæki. Að hluta til virðist hann reyndar ekki telja okkur standa mjög aftarlega, en pað séu engu að síður tækifæri til að gera enn betur.

Ég held að pað sé hægt að einfalda kerfið. Ég held að sumir hlutir séu of flóknir [...] ef maður rankar pað hversu auðvelt er að stofna fyrirtæki, pá erum við i top 15 held ég, en við gætum verið i top 5 eða 3. [...] Við gætum gert petta hraðar ... pað er mikilvægt fyrir pá sem eru að standa í fyrirtækjarekstri að reglurnar séu skýrar einfaldar og almennar. Að petta sé ekki undanpágubusiness heldur skýrar einfaldar reglur.

Jafnvel pó ekki væri um styrk að ræða, fannst viðmælendum pess virði að kaupa ráðgjöf til að komast í gegnum reglugerðarumhverfið. „Dó að sá kostnaður hafi verið hár og hafi sviðið á peim tíma reyndist pað gód fjárfesting" (viðmælandi F). Allir viðmælendur ræddu mikilvægi pess að hafa einfalt regluverk. Dað er poí brýn nauðsyn að stjórnmálamenn vinni að pví að setja fyrirtækjum einfaldar og skilvirkar starfsreglur (viðmælandi C). Reglugerðarumhverfi Íslands parf að vera samnefnari yfir:

\section{[...] lög sem allir pekkja, pvælast ekki fyrir neinum fjárfestum, pvælast heldur ekki fyrir ef einhver vill kaupa fyrirtækið [...] Detta snýst bara um ef einhver lögfræð- ingur spyr hvar eruð pið staðsettir, pá veit hann allt um pað og pá parf enginn að leggja neitt á sig til að kaupa pig eða fjármagna (viðmælandi F).}

Meirihluti viðmælenda hafði orð á hve skráningargjöld við stofnun fyrirtækis á Íslandi væru há og töldu stofnkostnað vera einn af hæstu pröskuldum sem ung fyrirtæki pyrftu að eiga við. Aðrir töldu reyndar, pvert á móti, að skráningargjaldið mætti ekki vera of lágt, pví að ákveðin sía í skráningargjaldinu væri heppileg til að koma í veg fyrir að peir sem ekki væri næg alvara færu að stofna fyrirtæki, í sumum tilfellum á veikum grundvelli (viðmælandi C). Viðmælendur höfðu engu að síður margir á orði hve erfitt væri að koma fótum undir fyrirtæki sitt, töldu reglugerðarumhverfið flókið og of krefjandi að stofna fyrirtæki hér á landi. Meðal pess sem peir nefndu er krafa um skrásetningu á tilteknum hlut í félagi strax í upphafi. 


\begin{abstract}
Af poí að pegar pú ert að stofna fyrirtæki, pá er eignarhlutinn ekki almennilega ákvarðaður. Dú vilt ekki festa eignarhluta, mađur veit ekki hver dettur frá eftir hálft ár eða eitt ár. Dað getur skaðað fyrirtækið mikið ef einhver sem á stóran hlut fer síđan frá og vill ekki gefa hann frá sér. Eins og petta er erlendis, sérstaklega í BNA (Bandaríki Norður Ameríku), par sem er svona "vesting" fyrirkomulag, pá er pað i lögunum. Dað er ekki i lögunum hjá okkur. Dað verður alltaf einhver að eiga fyrirtækið hjá okkur, bæði upp á skatta og annað (viðmælandi A).
\end{abstract}

Annar páttur sem viðmælendum fannst vera ákveðin hindrun er stofnkostnaðurinn og krafan um lágmarkshlutafé, en pó voru viðmælendur ekki á einu máli um hversu mikil hindrun pað væri.

\begin{abstract}
„Hvað er hann ekki 130.000 og hlutaféd upp á einhverja hálfa. Detta er í pað hæsta myndi ég segja. Detta er viðráðanlegt, en maður er ekkert að hoppa til. Dað er ekki fyrr en maður er búinn að fullvissa sig að petta sé pað sem maður vill. Við stofnuðum ekki okkar fyrirtæki fyrr en við fegnum inn hlutafé eða vorum með pað fyrir víst. Annars erum við ekki komnir of langt." (viðmælandi A)
\end{abstract}

"Dessi 130 kall (AR: skráningargjaldið), ætli petta sé ekki nálægt pví að vera kostnaðarverð. Detta er ekki eitthvað sem ég held að sé frágangssök fyrir marga, pó að petta sé pó eitthvað. Flestir sem fara af stað í dag eru farnir að gera fullt af hlutum ádur en peir formlega stofna fyrirtækið, prófa hugmyndina ádur en að kostnaðinum kemur. I mínum huga er petta ekki eitthvað sem ... já petta er bara ásættanlegt , pó að megi lækka kröfuna um lágmarkshlutafé." (viðmælandi E).

Pó nefndi viðmælandi E, raðfrumkvöðull sem komið hefur að stofnun og rekstri margra frumkvöðlafyrirtækja, tvö lönd eða svæði, Delaware í Bandaríkjunum og Írland, par sem frumkvöðlafyrirtæki hafa náð góðum árangri, en í pessum löndum kostar nánast ekkert að skrá ný fyrirtæki, og fannst honum umhugsunarvert að Íslendingar tækju petta til fyrirmyndar.

Að mati viðmælenda er pað pví fyrst og fremst flækjustigið í reglugerðarumhverfinu sem mætti minnka, auk pess sem kröfur um lágmarkshlutafé eru frekar háar að mati sumra peirra.

\title{
3.2.2 Almenn lagaumgjörð
}

Flestir viðmælendanna voru almennt nokkuð sáttir við lagaumgjörðina, en aðrir voru pað stutt komnir með fyrirtækið að peir höfðu ekki mikla skoðun á pví. „Lagaumhverfið er fínt, pað er fljótlegt að setja upp fyrirtæki og reglurnar eru skýrar" (viðmælandi A), en sem dæmi nefndi hann að endurgreiðsla á rannsóknar og próunarkostnaði hafi verið einföld í framkvæmd. Рað helsta sem peim fannst um lagaumgjörðina er hve breytileg hún er og hversu mikil óvissa er um hana. Töldu viðmælendur skort á heildarsýn og langtímaplani há íslenska regluverkinu, [...] við erum bara að taka ad hoc (ísl. sérsniðinn) plástra hér og par [og] pað parf að vera strategískari nálgun á ákvarðanatöku. Ekki svona plástrar, pví mér finnst petta vera of skammtímamiðuð hugsun" (viðmælandi B). Pá nefndu sumir viðmælendanna styrki undir pessum lið, en einn peirra nefndi í pessu samhengi, að styrkir sem eingöngu eru ætlaðir konum væru ekki til pess gerðir að einfalda regluverkið. Gagnrýnin sneri ekki að styrkinum sem slíkum, heldur að slíkar sértækar lausnir væru ekki til pess fallnar að gera umhverfið einfaldara, straumlínulagaðra og auðveldara að vinna í. Umræða um lagaumgjörðina tengdist einnig nokkuð Evrópusambandinu og að vera hluti af pví regluverki, enda nær aðeins hluti pess hingað til lands í gegnum evrópska efnahagssvæðið. Viðmælandi $\mathrm{F}$ telur til dæmis mikil tækifæri vera fyrir hendi að búa til eins almennt og staðlað lagaumhverfi og hægt er og að raunverulega ætti að taka skrefið til fulls í samlögun að 
lagaumhverfi Evrópusambandsins. „Til að auðvelda viðskipti, vera partur af stærra markaðssvæði, [...] EES er auðvitað að bjarga okkur í pessu samhengi“" (viðmælandi F).

\subsubsection{Skattaumhverfi}

Sá páttur sem viðmælendur töldu Ísland standa sig einna verst í varðar tekjuskatt. Telja peir skattbyrðina háa, bæði ef horft er til skattpreps fyrir hátekjufólk og meðalskattbyrði, auk pess sem flækjustig skattkerfisins var talið mikið. Pessi páttur var helsta áhyggjuefni viðmælenda, og hindrun í framgangi frumkvöðlafyrirtækja, sérstaklega á upphafsárum fyrirtækjanna. Par vó pyngst, að samkvæmt lögum er frumkvöðlum ekki heimilt að vinna launalaust í págu fyrirtækis síns. Er par vísað til pess að einstaklingar verða að reikna sér laun sem samræmast peim taxta sem gengur og gerist í samfélaginu, en geta ekki gefið lægri laun upp til skatts (viðmælandi F). Pessi lög gera að verkum að forsvarsmenn ungra fyrirtækja, sem ekki hafa mikinn pening milli handanna, hafa ekki leyfi til að vinna ókeypis í págu eigin fyrirtækis án pess að brjóta lög. Enn fremur kom fram að skattaívilnanir til frumkvöðlafyrirtækja eru afar takmarkaðar.

Við erum ekki komir með neinar tekjur ennpá pannig að við erum bara að lifa af pessu hlutafé. Баð væri náttúrulega alveg frábært ef pað væru einhvers konar skattaívilnanir sem maður gæti kannski síðar meir unnið til baka. Nú erum við búnir að ganga vel á hlutaféð og pegar við förum að fá tekjur verða pær mjög lágar til að byrja með og vaxa hægt. Pað væri mjög gott að fá einhvern stuðning par. Mér finnst erfitt að vera að borga stóran hluta af fjárfestingunni minni í skatt ádur en fyrirtækið er komið á legg (viðmælandi A).

Ein peirra leiða sem frumkvöðlafyrirtæki hafa helst upp á að bjóða til að laða til sín hæfa starfsmenn án pess að hafa efni á að borga peim full laun eru kaupréttarsamningar (Bagley, 2008; viðmælandi E). Umhverfi kaupréttasamninga og hlutabréfaívilnana var nefnt af viðmælendum sem sá páttur í lagalega umhverfinu sem pyrfti helst að bæta (viðmælendur A, E og F). Töldu peir reglur um skattlagningu kaupréttar gífurlega óhagkvæmar og órökrétt að skattleggja einstaklinga áður en nokkur raunverulegur hagnaður verður til. Við pá löggjöf sem var við lýði pegar rannsóknin var framkvæmd var skattlagning miðuð við pað pegar aðili móttekur verðmæti hvort sem pau eru í formi peninga eða í öðru formi (Alpingi, 2003). Hefur pað í för með sér að einstaklingur sem nýtir sér kaupréttarsamning ber að greiða skatt af honum við pað eitt að vinna sér inn pau réttindi. Töldu viðmælendur petta fyrirkomulag óeðlilegt par sem í frumkvöðlafyrirtækjum er líklegra en ekki að verðmæti hlutabréfa verði ekki neitt. Kaupréttir eru einn helsti hvati frumkvöðlafyrirtækja sem ekki hafa mikið fjármagn milli handanna að laða til sín hæfileikaríka starfsmenn, sem eru nauðsynlegir fyrirtækinu (viðmælandi E; Drucker, 1999).

Annað atriði sem viðmælendur töldu takmarkandi pátt í skattaumhverfinu er skattlagning sem erlendir sérfræðingar greiða af tekjum sínum hérlendis. Á öðrum Norðurlöndum njóta erlendir sérfræðingar hagstæðari skattakjara en innlendir aðilar. Pær ívilnanir eru misjafnlega háar í prósentum talið, auk pess sem afslátturinn gildir til mismunandi árafjölda. Er munurinn í Danmörku sérstaklega eftirtektarverður, en par greiða erlendir sérfræðingar 25\% í tekjuskatt á meðan almenn skattbyrði er um 52\%. Ef litið er til Norðurlandanna er skattbyrði erlendra sérfræðinga hæst á Íslandi (Viðskiptaráð, 2014). Flækjustigið í skattkerfinu var einnig viðfangsefni sem viðmælendum var hugleikið; peir töldu pað bæði of flókið og of kostnaðarsamt. Minntust peir meðal annars á að skattakerfið tæki ekki mið af pörfum frumkvöðlafyrirtækja og væri of óbilgjarnt í nálgun sinni. „Degar frumkvöðlafyrirtæki eru á viðkvæmu stigi snemma á liffserli sínum getur skattbyrðin reynst peim ofviða" (viðmælandi A). Drátt fyrir að nokkrar umbætur hafi átt sér stað frá pví að viðtölin í pessari rannsókn fóru fram er skattkerfið á Íslandi enn flókið, en samkvæmt nýútkominni skýrslu PWC og World Bank Group (Weeghel o.fl., 2017) er flækjustigið meira en víða annars staðar. Ísland 
skipar par 18. sæti yfir lönd í Evrópusambandinu og EFTA, sem er lakasta niðurstaða á Norðurlöndunum.

\subsection{Sampætt niðurstaða úr báðum hlutum rannsóknarinnar}

Nú verða dregnar saman niðurstöður úr báðum hlutum rannsóknarinnar, p.e. um stöðuna á Íslandi á grundvelli viðtalanna og hún sett í samhengi við stöðuna á hinum Norðurlöndunum.

\subsubsection{Skráning og skrifræði}

Í Nger greiningunni (Nordic Growth Entrepreneursip Review) fékk Ísland nokkuð góða einkunn, 79 (af 100), fyrir kröfur um skriffinsku, sem er svipað og á hinum Norðurlöndunum, en í skýrslunni er sérstaklata minnst á og talið jákvætt hve skamman tíma pað tekur að stofna fyrirtæki á Íslandi. Hins vegar dregur stofnkostnaður fyrirtækja einkunn pessa páttar niður (Napier o.fl., 2012). Petta er í samræmi við niðurstöður úr eigindlegu rannsókninni, en par var sérstaklega minnst á bæði pessi atriði. Pað er hins vegar áhyggjuefni að einkunn fyrir kröfur um skriffinsku fór niður á tímabilinu 2008-2012, eða úr 83 í 79 á meðan staðan í hinum Norðurlöndunum fór frekar batnandi. Hins vegar var sérstaklega minnst á рað í Nger greiningunni að lög um gjaldprotameðferð á Íslandi væri hliðholl frumkvöðlum og hefði batnað (fór úr 85 í 87), en pað er almennt talið stuðla að aukinni grósku í frumkvöðlastarfsemi (Armour og Cumming, 2008). Рað var pví almennt samræmi á niðurstöðum beggja rannsóknaraðferðanna og studdu pær hvor aðra. Helsta viðbótin úr megindlegu rannsókninni er að staðan á Íslandi versnaði á tímabilinu 2008-2012, sem er óheppilegt og ástæða fyrir stjórnmálamenn að hafa í huga.

\subsubsection{Almenn lagaumgjörd}

Раð sem fjallað er um sem almenna lagaumgjörð í pessari grein er mælt í fjórum páttum í Nger greiningunni, vöru- og starfsmannalöggjöf, meðferð og fullnusta dómsmála, samkeppnislöggjöf og gjaldprotalöggöof. Ísland skoraði nokkuð hátt í fyrstu tveimur páttunum, 79 og 82, en fékk ekki nema 43 í einkunn fyrir samkeppnislöggjöf. Pá er athyglisvert að staða Îslands fór lítillega niður á við í öllum pessum páttum á samanburðartímabilinu (2008-2012) að undanskilinni gjaldprotameðferð. Flestir viðmælenda í eigindlegu rannsókninni voru almennt nokkuð sáttir við lagaumgjörðina, en einn viðmælendanna (viðmælandi F) nefndi pó að pað skorti festu í lagaumgjörðinni og einnig að pað myndi skapa tækifæri ef hún væri samræmd bví sem gerist í Evrópusambandinu enn frekar en átti sér stað pegar rannsóknin var framkvæmd, pví pá pyrftu erlendir fjárfestar ekki að setja sig inn í enn eitt lagaumhverfið. Viðmælendur minntust ekki sérstaklega á samkeppnislög undir pessum lið í rannsókninni, en var pó tíðrætt um pætti sem hamla samkeppnishæfni íslenskra fyrirtækja, en peir pættir falla undir liðinn skattaumhverfi í pessari grein.

\subsubsection{Skattaumhoerfi}

Tekjuskattar einstaklinga annars vegar og fyrirtækja- og eignaskattar hins vegar falla undir liðinn skattaumhverfi í pessari grein. Báðir pessir pættir fengu fremur slaka einkunn í Nger yfirlitinu, eða 42 og 67, sérstaklega pó tekjuskattur einstaklinga. Einkunnin fyrir báða pættina er pó ívið hærri en á hinum Norðurlöndunum, en pað parf varla að taka pað fram, að pau ríki eru almennt pekkt fyrir háa skatta. Sérstaka athygli vekur pó að einkunn fyrir fyrirtækja- og eignaskatta fór verulega niður á við á árunum 2008-2012, eða úr 89 í 67. Skattaumhverfið er sá páttur sem viðmælendum fannst mest hamlandi fyrir íslensk frumkvöðlafyrirtæki og pá sérstaklega tekjuskattar einstaklinga. Par ber helst að nefna kröfur um að skattleggja tekjur frumkvöðla út frá meðallaunum, sem í sumum tilfellum er nokkuð há fjárhæð, án pess að frumkvöðlarnir séu byrjaðir að greiða sér tekjur. petta leiðir til pess að stór hluti af peim takmörkuðu fjármunum sem peir hafa aflað til rekstursins fari í greiðslu á sköttum. Annar páttur sem er hamlandi, er að ekki eru sér- 
stök ívilnunarákvæði um skattlagningu á tekjum erlendra sérfræðinga eins og algengt er á hinum Norðurlöndunum. Priðji pátturinn sem viðmælendur töldu sérstaklega óhagstætt er skattlagning kaupréttarsamninga. Niðurstöður beggja hluta rannsóknarinnar fara vel saman og styðja hvorn annan, en eigindlega rannsóknin veitti pó dýpri innsýn í málefnið eins og gjarnan á sér stað. Á hinn bóginn komu fram gagnlegar upplýsingar um próun mála á Íslandi í megindlegu rannsókninni.

\subsubsection{Einkaréttarlöggjöf og staðlar}

Einkaréttarlöggjöf og staðlar eru einn páttur í reglugerðarumhverfinu samkvæmt Nger yfirlitinu, en eru pó ekki flokkaðir sem hluti af reglugerðarumhverfinu samkvæmt svipaðri rannsókn OECD (Ahmad og Hoffmann, 2008). Pessir pættir voru ekki teknar fyrir í eigindlegu rannsókninni, enda áttu peir ekki við um nema takmarkaðan hluta viðmælendanna. Рað var pví talið að eigindlega rannsóknin hefði ekki bætt neinu við í pessu tilfelli. Pessi páttur fær hins vegar freka slaka einkunn í Nger yfirlitinu, eða 55, en athyglisverðast er pó að einkunnin hefur lækkað umtalsvert á tímabilinu 2008-2012, eða úr 72 í 55.

\section{Tækifæri til úrbóta}

Nú verður gerð grein fyrir próun mála hér á landi undanfarin ár, en ýmsar breytingar hafa verið gerðar til að bæta reglugerðarumhverfi frumkvöðla á peim tíma sem liðinn er frá pví rannsóknin var framkvæmd. Ber par einna helst að geta frumvarps til laga um breytingu á ýmsum lögum til að styðja við fjármögnun og rekstur nýsköpunarfyrirtækja og smærri fyrirtækja í rekstri (Alpingi, 2016), en par er tekið á tveimur mikilvægum atriðum sem komu fram í pessari rannsókn, skattlagningu kaupréttar og skattlagninu á tekjum erlendra sérfræðinga. Með breytingunni er skattlagning kaupréttar orðin sambærileg við pað sem gerist á hinum Norðurlöndunum og mikilvæg breyting var gerð á skattlagningu á tekjum erlendra sérfræðinga. Að mati Viðskiptaráðs Íslands (Frosti Ólafsson, Björn B. Björnsson, Margrét B. Sverrisdóttir, Marta G. Blöndal og Sigurður Tómasson, 2016; Viðskiptaráð, 2016) er óparfa flækjustig í framkvæmd reglugerðarinnar, en samkvæmt henni eru gerðar kröfur um að fram fari sérstakt mat á pví hverjir teljist sérfræðingar við veitingu skattalegra ívilnana, en pess er ekki krafist í hinum Norðurlöndunum. Par að auki var tekið á öðrum mikilvægum málum, svo sem skattaafslætti vegna hlutabréfakaupa og hækkun á hámarki frádráttar til skatts vegna rannsóknar og próunarkostnaðar. Hér var pví um mikilvæga breytingu að ræða sem sýnir vilja stjórnvalda til að bæta reglugerðarumhverfi frumkvöðla.

Bæði í fræðilegri umfjöllun og í greiningu á núverandi stöðu kom fram mikilvægi pess að reglugerðarumhverfi sé skýrt, einfalt og markvisst (viðmælandi C; Keuschnigg og Nielsen, 2004). Slíkt umhverfi hefði ótvíræða kosti í för með sér, en bæði myndi minni kostnaður leggjast á stjórnvöld og frumkvöðlar ekki purfa að eyða jafn miklum tíma og fjármunum og annars væri raunin (viðmælandi E; Kitching o.fl., 2013). Gott dæmi um petta flækjustig má sjá í skattkerfinu, en tekjuskattur var meðal peirra pátta í íslenska reglugerðarumhverfinu sem fengu hvað lægstu einkunn í Nger yfirlitinu. Prátt fyrir að nokkrar breytingar hafa verið gerðar frá pví að viðtölin fóru fram, virðist engu að síður sem enn séu tækifæri til að bæta skattaumhverfið, en í úttekt Efnahagssviðs Samtaka atvinnulífsins á starfsumhverfi íslenskra fyrirtækja, sem kynnt var á morgunverðarfundi Samtaka iðnaðarins 15. Febrúar 2017 kom fram að Ísland væri háskattaland, skattkerfið óskilvirkt og flækjustigið mikið (Ása Kristjánsdóttir, Óttar Snædal og Tryggvi Másson, 2017).

Loks má nefna, að sumir viðmælendur í eigindlegu rannsókninni töldu að skráningargjald fyrir stofnun fyrirtækja væri fremur hátt, svo og að kröfur um lágmarkshlutafé væru pungar. Ekki voru pó allir sammála um petta, en rétt er að geta pess að kröfur um lágmarkshlutafé eru ekki útgjöld, heldur fjármunir sem nýtast í starfsemina pegar hún er komin af stað. Engu að síður taldi einn viðmælendanna, raðfrumkvöðull sem hefur töluverða reynslu og pekkingu af stofnun og rekstri frumkvöðlafyrirtækja (viðmælandi F), pað 
umhugsunarvert að hafa skráningargjaldið nánast ekkert (2 US\$), svipað og í Delaware og Lúxemborg, par sem slík breyting myndi stuðla að enn frekari frumkvöðlastarfsemi.

\section{Umræður}

Í pví heimsvædda umhverfi sem fyrirtæki starfa eru pau ekki lengur jafn bundin landfræðilegri staðsetningu sinni og pau voru áður; ef pau telja hagstæðara að framleiða vöru í tilteknu landi, færa pau einfaldlega framleiðsluferlið pangað. Undanfarin ár hafa sum frumkvöðlafyrirtæki brugðið á pað ráð að skrá fyrirtækin erlendis við stofnun eða síðar á æviskeiðinu, líkt og Actavis, Bakkavör og Promens. Ástæður pessarar ákvörðunar fyrirtækjanna eru margar og mismunandi, en rannsóknir benda til pess að reglugerðarumhverfið sé meðal peirra pátta sem geta haft áhrif á árangur frumkvöðlafyrirtækja (OECD, 2012) og par af leiðandi væntanlega á ákvörðun peirra um hvar fyrirtækið er skráð. Hins vegar verður pessi próun að teljast áfellisdómur yfir rekstrarumhverfi á Íslandi en pessari próun fylgir mikill kostnaður auk pess sem pjóðartekjur verða minni en ella. Par sem mikill kostnaður fylgir pví að fyrirtæki hverfi úr landi, sérstaklega pekkingarfyrirtæki (McKinsey-Scandinavia, 2012), auk pess sem pjóðartekjur verða minni en ella og samkeppnishæfni pjóðarinnar lakari, er mikilvægt að fá innsýn í pætti sem gætu verið áhrifavaldar pessarar próunar. Í pessari rannsókn er einn peirra tekinn til skoðunar en pað er reglugerðarumhverfið. Rannsóknarspurningin sem sett var fram í pessu skyni er:

Hvernig er staðan í reglugerðarumhverfi frumkvöðla á Íslandi og hvar gætu helstu tækifæri stjórnvalda til úrbóta legið með hliðsjón af stöðunni í löndum sem við getum helst borið okkur saman við?

Pessi rannsókn sýndi að staðan í reglugerðarumhverfinu á Íslandi er nokkuð góð. Engu að síður eru enn til staðar tækifæri fyrir Ísland til að gera endurbætur á nokkrum páttum í reglugerðarunhverfinu par sem Ísland er enn eftirbátur miðað við aðrar pjóðir, en pær snúa helst að skattamálum og stöðugleika í lagaumhverfinu. Enn fremur komu fram vísbendingar um að kröfur um stofnframlag og skráningargjöld væru hugsanlega ívið miklar. Rannsóknin leiddi jafnframt í ljós að staðan í reglugerðarumhverfi frumkvöðla fór hlutfallslega versnandi á Íslandi á árunum 2008 - 2012 í samanburði við hin Norðurlöndin (Napier o.fl., 2012). Ýmsar endurbætur hafa pó verið innleiddar eftir pann tíma, en ekki fundust rannsóknir um samanburð á stöðunni á Íslandi við hin Norðurlöndin eftir pær breytingar við vinnslu pessarar greinar. Nýleg rannsókn leiddi hins vegar í ljós, að pó svo að İslendingar séu frekar framarlega í nýsköpun stöndum við öðrum Norðurlandapjóðum nokkuð að baki, en Ísland skipar 25. sæti í nýsköpunarvísitölu Bloomberg á meðan hin Norðurlöndin eru í 2. - 14. Sæti (Jamrisko og Lu, 2017). Pessi niðurstaða gefur til kynna að ástæða sé til að rýna nánar í hvað veldur pessum mun og kanna sérstaklega hvort við getum dregið einhvern lærdóm af aðstæðum á hinum Norðurlöndunum.

Par sem reglugerðarumhverfið hefur ólík áhrif eftir pví hversu langt fyrirtækin eru komin, en helstu tímabilin sem fjallað er um eru annars vegar stofnun fyrirtækjanna og hins vegar eftir að rekstur er hafinn, er ekki nægjanlegt að skoða áhrif pess í heild sinni, heldur parf að skoða pau út frá pessum ólíku tímabilum. Reglugerðarumhverfi frumkvöðla hvað varðar stofnun fyrirtækja er nokkuð gott á Íslandi í samanburði við hin Norðurlöndin. Petta styður fyrri rannsóknir sem sýna fram á að áhugi Íslendinga á að stofna frumkvöðlafyrirtæki er mikil í samanburði við aðrar pjóðir (Kelley, Bosma og Amorós, 2011a). Hins vegar benda niðurstöður rannsóknarinnar til pess að nokkrir pættir í reglugerðarumhverfinu hafi neikvæð áhrif á árangur frumkvöðlafyrirtækja sem eru komin af stað og eru í vexti. Flókið skattaumhverfi og ípyngjandi skattstofnar virka letjandi og draga úr samkeppnishæfni fyritækja á erlendum mörkuðum (Braunerhjelm og Eklund, 2014). Par má til dæmis nefna kröfur um að frumkvöðlar standi skil á sköttum af mun hærri launum en peir greiða sér; skattaumhverfi af pessu tagi dregur úr fjárstyrk fyrirtækjanna og leiðir 
til pess að pau ná minni árangri en ella. Enn fremur leiðir rannsóknin í ljós tækifæri til breytinga á skattkerfinu sem myndu auka aðgengi að fjármagni, en skortur á pví er meðal veikustu pátta í umhverfi frumkvöðlafyrirtækja á Íslandi (Napier o.fl., 2012).

Ef Ísland vill búa til starfsumhverfi sem stuðlar að sem bestum árangri frumkvöðla, parf að vinna markvisst að pví að innleiða endurbætur á umhverfi peirra. Prátt fyrir smæð landsins er frumkvöðlavilji pjóðarinnar mikill (Kelley o.fl., 2011b). Til að bæta upp takmarkanir vegna smæðar markaðarins er mikilvægt að skapa starfsskilyrði sem eru með pví besta sem gerist í öðrum löndum, en reglugerðarumhverfið er einn af peim páttum sem ætti að vera tiltölulega auðvelt að endurbæta. Í litlum samfélögum er auðveldara að byggja upp tengslanet, auk pess sem samvinna virkar oft betur. Рað er mikilvægt að reglugerðarumhverfið sé pannig upp byggt að pað örvi og styðji slíka eiginleika svo peir fái að njóta sín og frumkvöðlafyrirtæki geti vaxið og dafnað allt æviskeið fyrirtækjanna. Pá er mikilvægt að hafa í huga, að jafnvel smávægileg frávik frá heppilegustu skilyrðum geta myndað flöskuháls og jafnframt að ef mikill munur er á einstaka páttum verða áhrifin enn meiri (Ács o.fl., 2014). Í pessari rannsókn kom fram að töluverður munur er á milli einstaka pátta, en samkvæmt niðurstöðum hennar er sérstaklega mikilvægt að hafa í huga stöðuna í skattamálum (tekjuskattar einstaklinga; fyrirtækja og eignaskattar) og samkeppnislöggjöf, en einnig voru vísbendingar um frekar laka stöðu í einkaréttarlöggjöf og stöðlum.

Ísland er einungis agnarsmár leikari á sviði hagkerfis á heimsvísu og landfræðilega fjarlægt vaxtarmörkuðum heimsins. Að sama skapi er efnahagsleg stjórnun landsins að mörgu leyti ólík pví sem á sér stað meðal peirra landa sem standa Íslandi framar í sköpun og próun frumkvöðlafyrirtækja. Íslensk stjórnvöld hafa sögulega stutt við bakið á peim atvinnugreinum sem taldar eru bera hitann og pungann af útflutningsverðmætum landsins. Ef frumkvöðlastarfsemi á að komast á sama stall og sjávarútvegur, ál-, og ferðamannaiðnaður standa á í dag, purfa íslensk stjórnvöld að skapa umhverfi sem gerir slíkt mögulegt. Stjórnvöld purfa að veðja á auðlindirnar sem búa í Íslendingum sjálfum og skapa umgjörð sem stuðlar að pví að pær fái að vaxa og dafna í íslensku samfélagi, en ekki aðeins auðlindir sem liggja djúpt í jörðu eða synda í hafinu umhverfis landið.

Í pessari rannsókn var einungis leitað að helstu tækifærum til endurbóta á reglugerðarumhverfi frumkvöðla, en ekki tæmandi yfirliti; pau virðast fyrst og fremst liggja í breytingum á skattaumhverfinu og einföldun á lagaumhverfinu. Prátt fyrir að skattaumhverfið sé að sumu leyti ágætt í samanburði við hin Norðurlöndin, pá leiddi pessi rannsókn í ljós nokkra pætti í pví sem ekki er vitað til að fjallað hafi verið um í fyrri rannsóknum og hægt er að endurbæta. Par er um að ræða pætti sem hafa einkum og sér í lagi neikvæð áhrif á nýstofnuð frumkvöðlafyrirtæki og pau sem eru á fyrstu árum starfseminnar. Enn fremur virðast tækifæri liggja í pví að einfalda skráningarferlið, hugsanlega að lækka skráningargjöld og minnka lágmarkskröfur um stofnframlag (t.d. lágmarks hlutafé). Sú er von okkar að pessi grein og niðurstöður rannsóknarinnar sem hún byggir á varpi ljósi á stöðu mála í reglugerðarumhverfi frumkvöðla og gefi til kynna tækifæri til úrbóta. Pað er hins vegar stjórnmálamanna að taka afstöðu til peirra ábendinga sem hér hafa verið settar fram og meta með hvaða hætti peir kjósa að breyta löggjöf og reglugerðarumhverfi til að auka samkeppnishæfni íslenskra fyrirtækja á Íslandi og erlendum mörkuðum.

\section{Takmarkanir}

Framangreindar niðurstöður byggja annars vegar á viðtölum sem fram fóru í lok ársins 2014 og endurspegla pann veruleika sem viðmælendur töldu gilda á peim tímapunkti og hins vegar á greiningu á samanburði á reglugerðarumhverfi á Norðurlöndunum sem unnin var á árinu 2012. Til að bæta úr pessum takmörkunum og auka gildi rannsóknarinnar var leitað upplýsinga um breytingar sem gerðar hafa verið síðustu misseri á Íslandi, allt til ársins 2017, en talsverðar breytingar hafa orðið á reglugerðarumhverfi frumkvöðla á peim tíma. Áhugavert væri að endurtaka rannsóknina, en mestur ávinningur fengist af slíku framtaki pegar ný greining á reglugerðarumhverfi erlendis, og pá sérstaklega á 
Norðurlöndunum, liggur fyrir. Enn fremur er líklegt að pað séu fleiri tækifæri til endurbóta en hér er fjallað um og er kjörið tækifæri að kanna pað nánar í frekari rannsóknum.

\section{Heimildaskrá}

Acs, Z. (2006). How is entrepreneurship good for economic growth? Innovations, 1(1), 97-107. Sótt af http:// www.mitpressjournals.org/doi/abs/10.1162/itgg.2006.1.1.97\#.WH0GJRuLSUk

Acs, Z. J., Arenius, P., Hay, M. og Minniti, M. (2004). Global entrepreneurship monitor: London, UK y Babson Park, MA: London School y Babson College. Sótt af http://www.emekin.net/documentos/eu/GEM_2004_ Exec_Report.pdf

Ahmad, N. og Hoffmann, A. (2008). A framework for addressing and measuring entrepreneurship: OECD, Entrepreneurship Indicators Steering Group. Sótt af http://www.oecd.org/officialdocuments/publicdisplaydocumentpdf/?doclanguage $=$ en\&cote $=\operatorname{std} / \operatorname{doc}(2008) 2$

Alpingi. (2003). Lög um tekjuskatt nr. 90/2003. Sótt 8. október 2014 af http://www.althingi.is/lagas/ nuna/2001036.html. Reykjavík: Alpingi.

Alpingi. (2016). Frumvarp til laga um breytingu á ýmsum lögum til að styðja við fjármögnun og rekstur nýsköpunarfyrirtækja og smærri fyrirtækja. Sótt 28. maí 2017 af http://www.althingi.is/altext/pdf/145/s/1096. pdf. Reykjavík: Alpingi

Armour, J. og Cumming, D. (2008). Bankruptcy law and entrepreneurship. American Law and Economics Review, 10(2), 303-350. Sótt af https://academic.oup.com/aler/article-abstract/10/2/303/160051

Ács, Z. J., Autio, E. og Szerb, L. (2014). National Systems of Entrepreneurship: Measurement issues and policy implications. Research Policy, 43(3), 476-494. doi:https://doi.org/10.1016/j.respol.2013.08.016

Ása Kristjánsdóttir, Óttar Snædal og Tryggvi Másson (15. febrúar 2017). Er eftirsóknarvert að vera eyland? Pjóðagslegt mikilvægi erlendrar fjárfestingar. á Er erlend fjárfesting á Íslandi blessun eða böl?, Reykjavík. Sótt af http://www.sa.is/frettatengt/frettir/erlend-fjarfesting-styrkir-stoedu-islands-og-baetir-lifskjoer/

Baumol, W. J. og Strom, R. J. (2007). Entrepreneurship and Economic Growth. Strategic Entrepreneurship Journal, 1(3-4), 233-237. doi:10.1002/sej.26

Black, S. E. og Strahan, P. E. (2002). Entrepreneurship and bank credit availability. Journal of Finance, 57(6), 2807-2833. doi:10.1111/1540-6261.00513

Braunerhjelm, P., Desai, S. og Eklund, J. E. (2015). Regulation, firm dynamics and entrepreneurship. European Journal of Law and Economics, 40(1), 1-11. doi:10.1007/s10657-015-9498-8

Braunerhjelm, P. og Eklund, J. E. (2014). Taxes, tax administrative burdens and new firm formation. Kyklos, 67(1), 1-11. doi:10.1111/kykl.12040

Bryman, A. (2007). Barriers to Integrating Quantitative and Qualitative Research. Journal of Mixed Methods Research, 1(1), 8-22. doi:10.1177/2345678906290531

Chowdhury, F., Terjesen, S. og Audretsch, D. (2015). Varieties of entrepreneurship: institutional drivers across entrepreneurial activity and country. European Journal of Law and Economics, 40(1), 121-148. doi:10.1007/ s10657-014-9464-x

Darnihamedani, P., Block, J. H., Hessels, J. og Simonyan, A. (2015). Start-up costs, taxes and innovative entrepreneurship. á Academy of Management Annual Meeting Proceedings. doi:10.5465/AMBPP.2015.14518abstract

Djankov, S. (2009). The Regulation of Entry: A Survey. World Bank Research Observer, 24(2), 183-203. doi:10.1093/wbro/lkp005

Djankov, S., La Porta, R., Florencio, L.-d.-S. og Shleifer, A. (2002). The regulation of entry. Quarterly Journal of Economics, 117(1), 1-37. doi:10.1162/003355302753399436

Dutta, S., Lanvin, B. og Wunsch-Vincent, S. (2016). The Global Innovation Index 2016: Winning with Global Innovation. Sótt af http://www.wipo.int/edocs/pubdocs/en/wipo_pub_gii_2016.pdf

Evans, J. W. og Gabel, A. L. (2014). Legal Competitive Advantage and Legal Entrepreneurship: A Preliminary International Framework. North Carolina Journal of International Law \& Commercial Regulation, 39(2), 333-422. Sótt af http://search.ebscohost.com/login.aspx?direct=true\&db=bsu\&AN=95640756\&site=ehost-live

Fernández-Serrano, J. og Romero, I. (2014). About the interactive influence of culture and regulatory barriers on entrepreneurial activity. International Entrepreneurship and Management Journal, 10(4), 781-802. doi:10.1007/s11365-014-0296-5

Frosti Ólafsson, Björn B. Björnsson, Margrét B. Sverrisdóttir, Marta G. Blöndal og Sigurður Tómasson. (2016). Leiðin að aukinni hagsæld: Próun efnahagsmála og framvinda umbóta frá útgáfu Íslandsskýrslu McKinsey. Sótt af http://vi.is/\%C3\%BAtg\%C3\%A1fa/sk\%C3\%BDrslur/leidin-ad-aukinni-hagsaeld.pdf

Fuentelsaz, L., Gonzalez, C., Maicas, J. P. og Montero, J. (2015). How different formal institutions affect opportunity and necessity entrepreneurship. Brq-Business Research Quarterly, 18(4), 246-258. doi:10.1016/j. brq.2015.02.001

González-Sánchez, V. M. (2015). Factors Promoting Entrepreneurship in European Countries: Unemployment, Taxes, and Education. Journal of Promotion Management, 21(4), 492-503. doi:10.1080/10496491.2015.1051 405 
Graham, S. J., Merges, R. P., Samuelson, P. og Sichelman, T. (2009). High technology entrepreneurs and the patent system: Results of the 2008 Berkeley patent survey. Í Berkeley Technology Law Journal (bls. 12551327).

Jamrisko, M. og Lu, W. (2017). These Are the World's Most Innovative Economies: Nordic nations dominate the top 15, while South Korea reigns supreme and Russia is dealt a huge blow. Bloomberg Markets. Sótt af https://www.bloomberg.com/news/articles/2017-01-17/sweden-gains-south-korea-reigns-as-world-smost-innovative-economies

Kelley, D. J., Bosma, N. og Amorós, J. E. (2011a). 2010 Global Report: Global Entrepereneurship Monitor. Sótt af http://www.gemconsortium.org/report/47109

Kelley, D. J., Bosma, N. og Amorós, J. E. (2011b). Global entrepreneurship monitor 2010 executive report [Report]: Babson College, Babson Park, MA, United States; Universidad del Desarrollo, Santiago, Chile; London Business School, London, United Kingdom. Sótt af http://dspace.library.uu.nl/handle/1874/228073

Keuschnigg, C. og Nielsen, S. B. (2004). Start-ups, venture capitalists, and the capital gains tax. Journal of Public Economics, 88(5), 1011-1042.

Kitching, J., Hart, M. og Wilson, N. (2013). Burden or benefit? Regulation as a dynamic influence on small business performance. International Small Business Journal, 130-147.

Kitching, J., Kašperová, E., Blackburn, R. og Collis, J. (2011). Small company abbreviated accounts: A regulatory burden or a vital disclosure. Sótt af https://www.icas.com/technical-resources/publication-small-company-abbreviated-accounts

Klapper, L., Laeven, L. og Rajan, R. (2006). Entry regulation as a barrier to entrepreneurship. Journal of Financial Economics, 82(3), 591-629. doi:10.1016/j.jfineco.2005.09.006

Kristjánsdóttir, E. S. og DeTurk, S. (2013). Cultural Insiders to Cultural Outsiders: Structure, Identity, and Communication in the Adaptation of Domestic, Involuntary Migrants. Howard Journal of Communications, 24(2), 194-211.

Levie, J. og Autio, E. (2011). Regulatory burden, rule of law, and entry of strategic entrepreneurs: An international panel study. Journal of Management Studies, 48(6), 1392-1419.

Litan, R. (2014). Entrepreneurship and Economic Growth. Í K. E. Bettcher, J. Kindle og F. Stroker (ritstj.), Creating the Environment for Entrepreneurial Success. Washington, US: Center for International Private Enterprise.

Lunati, M. (2010). The OECD-Eurostat Entrepreneurship Indicators Programme. A Multi-year expert meeting on enterprise development policies and capacity-building in science, technology and innovation (STI), Geneva.

Mayer-Schonberger, V. (2003). E-commerce, entrepreneurship, and the law: Reassessing a relationship. The Emergence of Entrepreneurship Policy: Governance, Start-Ups, and Growth in the US Knowledge Economy, 195.

Mayer-Schonberger, V. (2010). Law as Stimulus: The Role of Law in Fostering Innovative Entrepreneurship. ISJLP, 6(2), 153.

McKinsey-Scandinavia. (2012). Charting a Growth Path for Iceland: McKinsey \& Company. Sótt af https:// www.forsaetisraduneyti.is/media/Skyrslur/charting-a-growth-path-for-iceland-2012.pdf

Merriam, S. B. og Tisdell, E. J. (2015). Qualitative research: A guide to design and implementation. United States: John Wiley \& Sons.

Napier, G., Rouvinen, P., Johansson, D., Finnbjörnsson, T., Solberg, E. og Pedersen, K. (2012). The Nordic Growth Entrepreneurship Review 2012: Final report: Nordic Innovation. Sótt af http://www.nordicinnovation.org/Publications/nordic-growth-entrepreneurship-review-2012/

OECD. (2012). OECD science, technology and industry outlook 2012: OECD.

OECD. (2016). STI Outlook 2016 Country Profile: Iceland: OECD. Sótt af https://www.innovationpolicyplatform.org/content/iceland

Orbe, M. P. (1998). Constructing co-cultural theory: An explication of culture, power, and communication. London, New Dehli: Sage.

Tashakkori, A. og Creswell, J. (2007). Exploring the nature of research questions in mixed methods research. Journal of Mixed Methods Research, 1(3), 207-211.

Viðskiptaráð. (2014). Snúum vörn í sókn: Umhverfi erlendra sérfræðinga á Íslandi. Reykjavík: Viðskiptaráð Íslands. Sótt af http://www.vi.is/malefnastarf/utgafa/skodanir/2014-08/

Viðskiptaráð. (2016). Aukinn stuðningur við nýsköpun fagnaðarefni. Reykjavík: Viðskiptaráð Íslands. Sótt af http://vi.is/malefnastarf/umsagnir/aukinn-studningur-vid-nyskopun-fagnadarefni/

Weeghel, S. v., Lopez-Claros, A., Packman, A., Ramalho, R., Howlett, N., Nasr, J., . . Ulku, H. (2017). Paying Taxes 2017 [Report]: PWC; World Bank Group. Sótt af http://www.pwc.com/gx/en/services/tax/payingtaxes-2017.html

Woolley, C. M. (2009). Meeting the Mixed Methods Challenge of Integration in a Sociological Study of Structure and Agency. Journal of Mixed Methods Research, 3(1), 7-25. doi:10.1177/1558689808325774

Wunsch-Vincent, S., Lanvin, B. og Dutta, S. (2015). The Global Innovation Index 2015: Effective Innovation Policies for Development. Sótt af https://www.globalinnovationindex.org/userfiles/file/reportpdf/GII2015-v5.pdf 